\title{
ANALISIS UJI KARAKTERISTIK BIOETANOL DARI PISANG HUTAN TERHADAP VARIASI MASSA RAGI
}

\author{
Dady Sulaiman*, St Syahdan, Siti Maria Ulva
}

Jurusan Fisika, Universitas Kaltara

e-mail ${ }^{* 1}$ :dadysulaiman92@gmail.com

\begin{tabular}{c|c|c}
\hline Diterima 30 Oktober 2021 & Disetujui 22 Desember 2021 & Dipublikasikan 31 Desember 2021 \\
\hline \multicolumn{3}{|c}{ https://doi.org/10.33369/jkf.4.3.169-176 } \\
\hline
\end{tabular}

\begin{abstract}
ABSTRAK
Meningkatnya kebutuhan akan energi membuat beberapa peneliti mengembangkan sumber energi terbarukan seperti biomassa berbentuk bioetanol. Bioetanol merupakan energi alternatif yang menggunakan pati sebagai sumbernya. Pisang hutan merupakan salah satu tumbuhan yang mengandung pati dan mudah dijumpai di kabupaten Bulungan. Pisang ini tidak dikonsumsi oleh warga karena mengandung biji di dalamnya. Oleh karena itu limbah pisang hutan menjadi semakin meningkat karena tidak adanya pemanfaatan dari limbah tersebut. Berdasarkan permasalahan tersebut, maka perlu dilakukannya penelitian yang bertujuan untuk menguji karakteristik bioethanol dari pisang hutan terhadap variasi massa ragi. Tahapan metode penelitian yang akan dilakukan meliputi beberapa tahapan yaitu 1) pembuatan bioetanol, 2) tahap mengukur kadar etanol, dan 3) tahap uji karakteristik bioetanol. Tahapan pengujian bioetanol dilakukan uji karakteristik diantaranya: 1) Analisis Kadar Etanol, 2) Analisis Kadar Air, 3) Analisis densitas, 4) Analisis Specific Gravity dan API Gravity, 5) Analisis Nilai Kalor. Berdasarkan hasil penelitian yang diperoleh, kualitas bioetanol yang dihasilkan memiliki nilai densitas dan specific gravity sesuai dengan standar mutu bioetanol yaitu sebesar 0,78 pada ragi $3 \%$ dari bahan baku. Nilai kalor yang punya hubungan erat dengan API Gravity mendekati nilai maksimum pada standar mutu bioetanol yaitu sebesar 3702,30 kkal/kg pada ragi sebesar $5 \%$. Nilai kadar etanol yang paling besar diperoleh pada kadar jumlah ragi sebesar 5\% yaitu 24,8\%. Nilai kadar Air yang paling rendah diperoleh pada kadar jumlah ragi sebesar 3\% yaitu $75 \%$.
\end{abstract}

Kata kunci-Bioetanol, Pisang Hutan, Massa Ragi

\begin{abstract}
The increasing need for energy has made several researchers develop renewable energy sources such as biomass in the form of bioethanol. Bioethanol is an alternative energy that uses starch as a source. Forest banana is one of the plants that contain starch and is easily found in Bulungan district. This banana is not consumed by residents because it contains seeds in it. Therefore, forest banana waste is increasing due to the lack of utilization of the waste. Based on these problems, it is necessary to conduct research that aims to test the characteristics of bioethanol from forest bananas to the variation of yeast mass. The stages of the research method that will be done include several stages, namely 1) the manufacture of bioethanol, 2) the stage of measuring ethanol levels, and 3) the stage of testing the characteristics of bioethanol. The stages of bioethanol testing are characteristic tests, including: 1) Ethanol Content Analysis, 2) Water Content Analysis, 3) Density Analysis, 4) Specific Gravity and API Gravity Analysis, 5) Heat Value Analysis. Based on the research results obtained, the quality of bioethanol produced has the value of density and specific gravity in accordance with the quality standard of bioethanol which is 0.78 in yeast $3 \%$ of raw materials. The caloric value that has a close relationship with API Gravity is close to the maximum value of the bioethanol quality standard which is $3702.30 \mathrm{kcal} / \mathrm{kg}$ in yeast of 5\%. The value of the largest ethanol content was obtained at the total yeast content of 5\% which is $24.8 \%$. The lowest water content value is obtained at the total yeast content of $3 \%$ which is $75 \%$.
\end{abstract}

Keywords—Bioethanol, Forest Bananas, yeast mass

\section{PENDAHULUAN}

Menipisnya persediaan energi fosil mendorong penelitian dalam pengembangan sumber energi alternatif dari sumber daya alam yang bisa diperbaharui. Bentuk energi yang bisa diperbaharui salah satunya yaitu Biomassa (1-3). Biomassa berasal dari bahan organik dan dihasilkan melalui proses termodinamika yang dipengaruhi oleh temperatur dan volume (4). 
Hasil konversi biomassa berupa biogas, biodiesel, bioetanol dan sebagainya (5). Biomassa merupakan salah satu solusi bagi Indonesia untuk mendapatkan energi, karena Indonesia mempunyai potensi biomassa baik biodiesel maupun bioethanol. Biomassa yang akan diteliti berupa Bioetanol (1). Bioetanol adalah etanol yang dihasilkan dari fermentasi glukosa (gula) menggunakan bantuan ragi/yeast terutama jenis Saccharomyces cerevisiae $(1,6,7)$. Pemisahan bioetanol selanjutnya dilakukan dengan destilasi (8). Bioethanol biasanya menggunakan bahan baku tumbuh - tumbuhan. Bahan baku ini dikelompokkan menjadi tiga kelompok, yaitu bergula, serat selulosa dan mengandung pati $(1,9,10)$.

Faktor yang mendorong pembuatan bioetanol dari pisang hutan, salah satunya melihat dari hasil survei di daerah Kalimatan Utara tepatnya Kabupaten Bulungan bagian pedesaan, masih banyak terdapat pisang hutan (11). Pisang hutan adalah jenis tanaman liar yang tumbuh di hutan, dan tidak dikonsumsi oleh warga karena terdapat banyak biji pada pisang tersebut. Pisang hutan termasuk jenis tanaman yang paling mudah dan cepat dalam proses tumbuhnya. Jenis tanaman ini dapat tumbuh dimana saja, maka sangat disayangkan jika tidak dimanfaatkan dengan sebaik baiknya. Karena jenis pisang hutan ini bisa digunakan sebagai bahan bakar energi alternatif yang bisa diperbaharui dan ramah lingkungan dengan mengubahnya menjadi bioetanol.

Penelitian ini bertujuan untuk menguji karakteristik bioetanol menggunakan bahan dasar pisang hutan dengan menggunakan variasi ragi sebagai variabel bebasnya. Penelitian ini harus dilakukan untuk membantu warga sekitar memanfaatkan pisang hutan ini. Selain itu dengan adanya penelitian ini bisa membantu warga dalam bidang perekonomian.

\section{METODE PENELITIAN}

Jenis penelitian ini merupakan penelitian eksperimental laboratorium Pisang Hutan untuk mengetahui karakteristik bioetanol terhadap variasi massa ragi yang dapat digunakan sebagai sumber energi alternatif. Adapun alat-alat yang digunakan dalam penelitian ini adalah 1 paket alat destilator, Baskom plastik, Gelas Kaca, Gelas ukur 1000 ml, Kompor, Timbangan, Termometer, dan alkoholmeter. Bahan-bahan yang digunakan dalam penelitian ini adalah es batu, Pisang Hutan dan Ragi.

Tahapan Penelitian ini dilakukan dalam beberapa tahapan yaitu tahap pembuatan bioetanol, tahap Pengukuran kadar bioetanol, dan pengujian karakteristik bioetanol.

2.1 Tahap Pembuatan Bioetanol

Ada beberapa tahapan pembuatan bioetanol pada penelitian ini.

1. Menyiapkan bahan baku buah pisang hutan yang telah dikupas bersih.

2. Melakukan penghalusan pisang hutan. Pada tahap ini dilakukan penghalusan menggunakan gelas tanpa menghancurkan bijinya.

3. Selanjutnya difermentasi dengan menambahkan variasi massa ragi sebanyak $3 \%, 4 \%$, dan $5 \%$ dari total bubur pisang. (bahan baku yang digunakan sebanyak $1 \mathrm{~kg}$ )

4. Menutup rapat wadah fermentasi agar tidak terkontaminasi dan fermentasi berlangsung secara anaerob yaitu tak memerlukan udara. Proses fermentasi berlangsung selama 7 hari dan setelah itu bubur pisang akan berubah menjadi 3 lapisan, yaitu lapisan berupa endapan protein, dan diatasnya adalah air dan etanol.

5. Memisahkan endapan protein yang ada di larutan etanol menggunakan proses penyaringan. Hasilnya yaitu larutan etanol yang masih mengandung air siap untuk diproses ke tahap selanjutnya yaitu proses destilasi.

6. Melakukan proses destilasi untuk memisahkan etanol dari larutan hasil fermentasi dengan cara memanaskan larutan tersebut dengan menjaga suhu pemanasan pada titik didih etanol $78^{\circ} \mathrm{C}$, sehingga etanol lebih dahulu menguap dan penguapan tersebut dialirkan pada pipa, terkondensasi dan kembali lagi menjadi etanol cair.

2.2 Tahap Pengukuran Kadar Bioetanol.

Tahapan ini dilakukan dengan cara memasukkan bioetanol ke dalam gelas ukur atau tabung atau botol yang tingginya lebih panjang dari panjang alkohol meter. Kemudian memasukkan batang alkohol meter ke dalam gelas ukur. Alkohol meter akan tenggelam dan batas airnya akan 
menunjukkan berapa kandungan alkohol di dalam larutan tersebut.

2.3 Tahap Pengujian Karakteristik Bioetanol

1. Analisis Kadar Air Bioetanol

Pada Uji kadar air bioetanol, dilakukan dengan menghitung berat awal hasil fermentasi dikurangi berat akhir setelah didestilasi dibagi dengan berat awal. Adapun perumusan dalam menghitung kadar air, yaitu :

$$
\text { Kadar air }(\%)=\frac{\mathrm{A}-\mathrm{B}}{\mathrm{A}} \times 100 \%
$$

Dimana $A=$ Berat Sampel Awal $(\mathrm{ml})$ dan B = Berat Sampel Akhir $(\mathrm{ml})$

2. Analisis Densitas

Densitas merupakan jumlah suatu zat yang terkandung pada suatu volume. Berdasarkan syarat mutu bioetanol dari Badan Standar Nasional, densitas maksimal 0,8215 gr/ml. Densitas bioetanol diperoleh dengan membagi massa bioetanol dengan volumenya (12). Dimana massa bioetanol adalah selisih massa antara piknometer kosong dan yang berisi bioetanol.

$$
D s=\frac{m b}{v b}
$$

Dimana Ds $=$ Densitas Bioetanol $(\mathrm{gr} / \mathrm{ml}), \mathrm{mb}=$ Massa Bioetanol $(\mathrm{gr})$ dan $\mathrm{vb}=$ Volume Bioetanol $(\mathrm{ml})$

\section{Analisis Specific Gravity dan API Gravity}

Nilai Specific Gravity (sg) sebanding dengan nilai densitas, Nilai ini merupakan berat per satauan voume dari suatu bahan. Adapun hubungan antara specific gravity (sg) dan API gravity $(\mathrm{G})$ adalah sebagai berikut.

$$
G=\frac{141,5}{s g}-131,5
$$

Besarnya harga dari API Gravity berkisar dari 0 - 100, sedangkan specific gravity merupakan harga relatif dari densitas suatu bahan terhadap air. Nilai densitas, Specific gravity dan API gravity kemudian digunakan untuk menghitung nilai kalor. Hubungan antara densitas dan specific gravity adalah sebagai berikut.

$$
s g=\frac{\operatorname{density}\left(\frac{\mathrm{kg}}{\mathrm{m}^{3}}\right)}{\text { density } \operatorname{air}\left(\frac{\mathrm{kg}}{\mathrm{m}^{3}}\right)}
$$

Dimana $\mathrm{G}=$ API Gravity dan $\mathrm{sg}=$ specific gravity

\section{Analisis Nilai Kalor}

Analisis ini bertujuan untuk mengetahui energi kalor yang dihasilkan pada setiap komposisi bioetanol yang akan diuji. Nilai kalor (NK) dapat dihitung menggunakan persamaan berikut (12):

$$
N K=\frac{2,2046226}{3,9673727} x(18,650+40 x(G-10) \mathrm{kkal} / \mathrm{kg})
$$

Dimana NK = Nilai Kalor $(\mathrm{kkal} / \mathrm{kg})$ dan G = API Gravity yang diperoleh dari hasil perhitungan pada persamaan $(2.3)$

\section{HASIL DAN PEMBAHASAN}

3.1 Hasil Penelitian

Tahapan yang dilakukan pada penelitian ini adalah melakukan pengolahan bahan, melakukan fermentasi, destilasi dan menganalisis karakteristik bioetanol. Analisis kualitas bioetanol mnggunakan analisis Kadar air, Kadar etanol, Densitas, Specific Gravity dan API Gravity, dan Nilai Kalor

Pembuatan bioetanol dimulai dengan menyiapkan bahan baku buah pisang masak yang telah dikupas bersih dan dihaluskan menggunakan gelas tanpa menghancurkan bijinya. Selanjutnya dilakukan fermentasi dengan menambahkan beberapa variasi ragi yang diantaranya adalah sebanyak 3\% 4\% dan 5\% dari total bubur pisang atau dari total bahan baku yang digunakan. Bahan baku yang digunakan pada setiap variasi ragi sebanyak $1 \mathrm{~kg}$ pisang hutan.

Proses fermentasi dalam penelitian ini menggunakan waktu yang sama pada masing-masing kadar ragi yang diberikan yaitu selama 7 hari. Proses fermentasi berlangsung secara anaerob, yaitu 
tidak memerlukan udara. Hasil fermentasi akan menghasilkan tiga lapisan yaitu lapisan berupa endapan protein dan diatasnya adalah air dan etanol. Memisahkan larutan etanol dengan endapan protein dilakukan dengan proses penyaringan. Larutan etanol yang masih mengandung air siap untuk diproses ke tahap selanjutnya yaitu proses destilasi. Proses destilasi yang dilakukan untuk memisahkan etanol dari larutan hasil fermentasi dengan cara memanaskan larutan tersebut dengan menjaga suhu pemanasan pada titik didih etanol $78^{\circ} \mathrm{C}$ sehingga etanol lebih dahulu menguap dan penguapan tersebut dialirkan pada pipa terkondensasi dan kembali lagi menjadi etanol cair. Dilanjutkan ke tahap pengujian karakteristik bioetanol untuk mengetahui kualitas bioetnaol berbahan buah pisang hutan. Hasil pengujian diperoleh data pada tabel 1.

Tabel 1. Kualitas bioetanol buah pisang hutan

\begin{tabular}{lccc}
\hline \multirow{2}{*}{ Parameter Kualitas } & \multicolumn{3}{c}{ Jumlah Ragi } \\
\cline { 2 - 4 } & $3 \%$ & $4 \%$ & $5 \%$ \\
\hline Kadar etanol (\%) & 23,6 & 24,1 & 24,8 \\
\hline Kadar Air (\%) & 75 & 83 & 86 \\
\hline Densitas (gr/ml) & 0,78 & 0,67 & 0,46 \\
\hline Specific Gravity & 0,78 & 0,67 & 0,46 \\
\hline API Gravity & 49,9 & 79,6 & 176,1 \\
\hline Nilai Kalor (kkal/kg) & 897,19 & 1557,35 & 3702,30 \\
\hline
\end{tabular}

\subsection{Pembahasan}

1. Kadar Etanol

Hasil uji karakteristik terkait kadar etanol menunjukkan nilai kadar terbesar diperoleh pada kadar jumlah ragi sebesar 5\% dari bahan baku dengan kadar etanol sebesar 24,8\%. Sedangkan pada kadar jumlah ragi 3\% dari bahan baku diperoleh kadar etanol terendah sebesar 23,6\%. Pada jumlah ragi $4 \%$ dar bahan baku diperoleh kadar etanol sebesar $24,1 \%$. Perlakuan yang diterapkan selama proses fermentasi pada penelitian ini dilakukan selama 7 hari. Hal ini dilakukan karena peneliti mencari nilai kadar etanol yang tertinggi. Fermentasi bioetanol dapat didefinisikan sebagai proses penguraian gula menjadi bioetnol dan karbondioksida yang disebabkan enzim yang dihasilkan oleh massa sel mikroba (13).

Proses fermentasi yang digunakan mengacu pada paparan (14) yang menyatakan bahwa semakin lama waktu fermentasi, kadar bioetanol akan semakin meningkat sampai batas waktu tertentu dan kemudian akan terjadi penurunan. Hal ini dikarenakan pada waktu 6 hari perkembangan mikrobia sudah maksimum sedangkan pada waktu fermentasi lebih dari 6 hari kadar etanol akan turun. Selain melihat dari proses fermentasi, adapun proses destilasi yang dilakukan akan memengaruhi hasil kadar etanol. Dimana kadar glukosa yang diperoleh masih terlalu kecil dikarenakan proses destilasi yang dilakukan masih sederhana serta proses fermentasi yang belum optimal. Kadar glukosa yang diperoleh pada penelitian ini, salah satunya juga disebabakan tidak adanya pemberian nutrient pada bakteri pengurai sehingga kurang bekerja secara optimal dalam mengubah glukosa menjadi bioetanol.

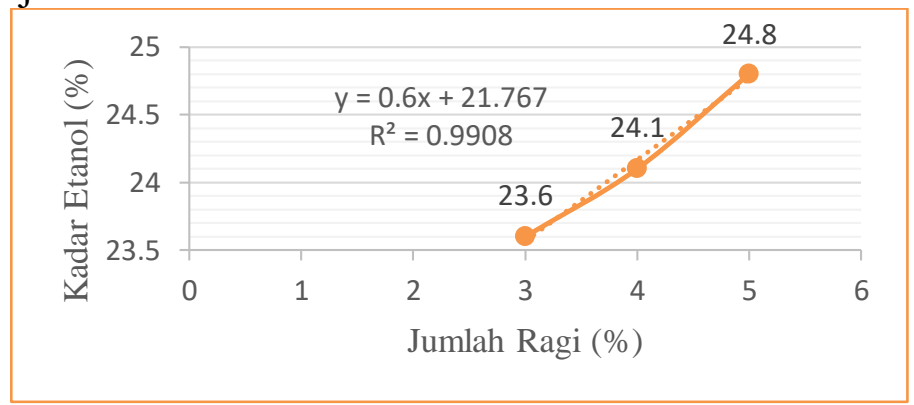

Gambar 1. Grafik Hasil Analisis Nilai Kadar Etanol

Terlihat pada Gambar 1 grafik hasil analisis kadar etanol menunjukkan bahwa semakin besar kadar jumlah ragi yang diberikan maka semakin meningkat pula kadar etanol yang dihasilkan. Hal ini disebabkan adanya penambahan massa ragi maka kadar etanol yang dhasilkan akan semakin besar. Terlihat pada gambar 1 yang menunjukkan nilai $\mathrm{R}^{2}$ mendekati 1 , maka dapat disimpulkan 
bahwa ada pengaruh yang signifikan variasi ragi terhadap kadar etanol yang terkandung pada sampel yang diberikan yaitu pisang hutan. hal ini disebabkan karena jumlah bakteri yang merubah glukosa menjadi etanol semakin besar seiring dengan penambahan kadar ragi. Proses ini akan terhenti jika kadar alkohol tidak dapat ditolerir oleh mikroba (15).

\section{Kadar Air}

Uji kadar air dilakukan dengan menghitung berat awal hasil fermentasi dikurangi berat akhir setelah didestilasi dibagi dengan berat awal. Kadar air yang dihasilkan dari beberapa variasi ragi menunjukkan bahwa kadar air tertinggi diperoleh dari kadar jumlah ragi sebesar 5\% dari bahan baku yaitu $86 \%$. Sedangkan kadar air terendah diperoleh dari kadar jumlah ragi sebesar 3\% dari bahan baku yaitu $75 \%$.

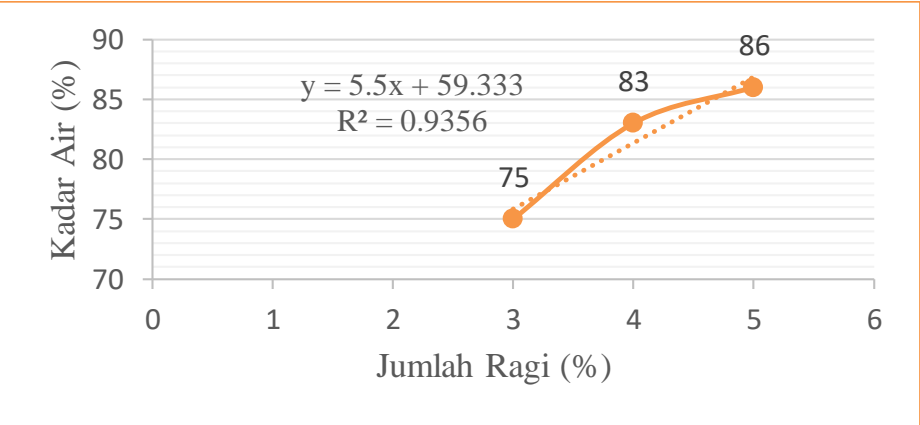

Gambar 2. Grafik Hasil Analisis Nilai Kadar Air

Berdasarkan Gambar 2 diatas, terlihat bahwa semakin besar jumlah kadar ragi yang diberikan maka semakin besar pula nilai kadar air yang diperoleh. Data yang dihasilkan dari penelitian ini menunjukkan bahwa nilai kadar air bioetanol belum memenuhi syarat mutu bioetanol dengan nilai maksimum 2\%. Hal ini disebabkan oleh etanol yang dihasilkan masih belum murni karena bercampur dengan air. Proses destilasi yang dilakukan adalah destilasi konvensional, sehingga etanol berbahan buah pisang hutan dengan variasi ragi masih banyak mengandung air. Semakin tinggi kadar air, kalor pembakaran akan semakin kecil (16). Terlihat pada gambar 2 terkait grafik hasil analisis kadar air menunjukkan nilai $\mathrm{R}^{2}$ mendekati 1 , artinya persamaan tersebut disimpulkan bahwa ada pengaruh terhadap kadar etanol yang terkandung pada sampel yang diberikan yaitu pisang hutan.

\section{Analisis Densitas}

Pada analisis densitas berdasarkan syarat mutu bioetanol yaitu maks $0,8215 \mathrm{gr} / \mathrm{ml}$. Nilai densitas yang dihasilkan dalam penelitian terlihat pada Tabel 1 diatas memenuhi syarat mutu bioetanol. Terlihat pada tabel bahwa adanya perbedaan hasil nilai densitas terhadap variasi ragi yang diberikan. Nilai densitas yang terkecil diperoleh pada campuran ragi sebesar 5\% yaitu 046 $\mathrm{gr} / \mathrm{ml}$. Sedangkan nilai densitas yang terbesar diperoleh pada campuran ragi sebesar $3 \%$ yaitu 0,78 $\mathrm{gr} / \mathrm{ml}$.

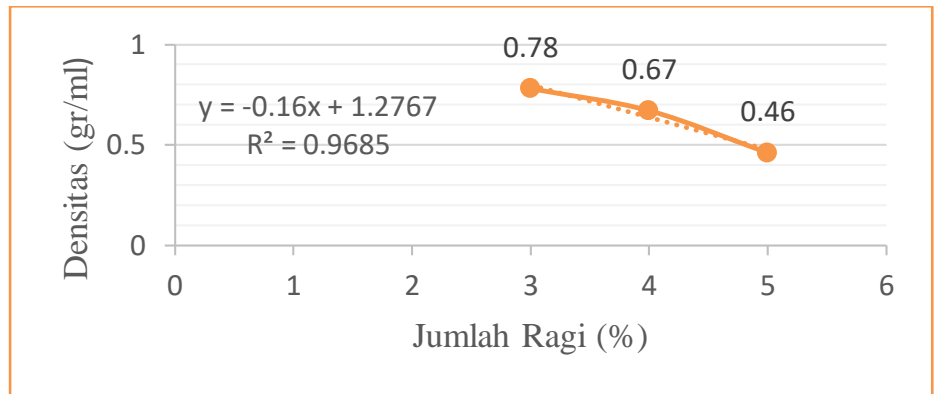

Gambar 3. Grafik Hasil Analisis Densitas

Berdasarkan grafik diatas terlihat bahwa semakin besar jumlah ragi yang digunakan maka semakin kecil nilai densitas yang dihasilkan. Hal ini terjadi dengan penambahan ragi pada uji densitas yang paling optimum pada perlakuan presentase ragi 5\%, memiliki hubungan erat dengan aktivitas mikroba yang mengalami pertumbuhan dan berkembang biak semakin banyak (14). Meningkatnya jumlah mikroba yang semakin banyak, maka jumlah karbohidrat yang terurai 
menjadi alkohol semakin besar. Jumlah alkohol yang semakin besar maka densitas dari bioetanol yang dihasilkan akan semakin rendah. Jumlah ragi yang tinggi maka semakin rendah nilai densitas yang dihasilkan. Hal ini karena sifat ragi yang merubah glukosa menjadi etanol, dimana jumlah ragi yang diberikan semakin banyak maka etanol yang dihasilkan juga akan semakin banyak sehingga densitas yang dihasilkan akan semakin rendah. Terlihat pada gambar 1 terkait grafik hasil analisis densitas menunjukkan nilai $\mathrm{R}^{2}$ mendekati 1 , artinya persamaan tersebut disimpulkan bahwa ada pengaruh terhadap kadar etanol yang terkandung pada sampel yang diberikan yaitu pisang hutan.

4. Analisis Specific Gravity dan API Gravity

Berdasarkan Tabel 1 hasil penelitian nilai Specific Gravity (sg) menunjukkan dimana hasil yang diperoleh sesuai standar baku mutu bioetanol maksimal sebesar 0,8215 yang ditetapkan oleh Badan Standar Nasional (BSN). Terlihat bahwa nilai Specific Gravity (sg) tertinggi diperoleh pada kadar jumlah ragi sebesar 3\% dari bahan baku yaitu 0,78. Nilai Specific Gravity (sg) pada kadar jumlah ragi sebesar $4 \%$ dari bahan baku yaitu 0,67 . Sementara nilai terendah dari hasil analisis Specific Gravity (sg) diperoleh pada kadar jumlah ragi sebesar 5\% dari bahan baku yaitu 0,46. Dari hasil penelitian ini menunjukkan bahwa bioetanol dari bahan buah pisang hutan memiliki kualitas yang sama besarnya dengan bioetanol berbahan nira kelapa yang rata-rata nilai Specific Gravity (sg) adalah sebesar 0,786 (17).

Terlihat pula pada Tabel hasil analisis API Gravity (G) memiliki nilai terendah pada kadar jumlah ragi sebesar 3\% dari bahan baku yaitu 49,9. Pada kadar jumlah ragi 4\% dari bahan baku diperoleh hasil analisis API Gravity (G) sebesar 79,6. Sementara nilai tertinggi dari hasil analisis API Gravity $(\mathrm{G})$ diperoleh dari kadar jumlah ragi sebesar 5\% dari bahan baku yaitu sebesar 176,1.

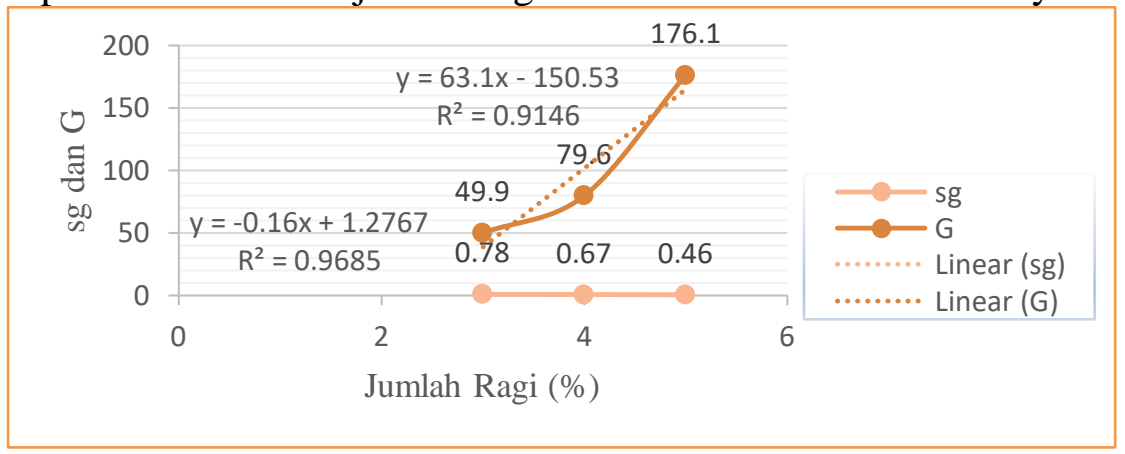

\section{Gambar 4. Grafik Hasil Analisis Densitas}

Grafik pada gambar 4 menunjukkan bahwa semakin besar jumlah kadar ragi yang digunakan maka nilai Specific Gravity (sg) akan semakin rendah. Sedangkan nilai dari analisis API Gravity diperoleh berbanding terbalik dengan analisis Specific Gravity (sg). Semakin besar jumlah kadar ragi yang diberikan diperoleh hasil analisis $G$ yang semakin besar. Nilai dari API Gravity mempunyai hubungan yang sangat erat dengan nilai kalor bioetanol. Hal ini dikarenakan nilai kalor berbanding lurus dengan nilai API Gravity. Semakin besar nilai API Gravity maka akan menyebabkan nilai kalor yang tinggi pula (17). Terlihat bahwa hasil analisis API Gravity tertinggi diperoleh pada jumlah kadar ragi sebesar 5\% dari bahan baku. Maka semakin besar jumlah kadar ragi yang diberikan akan mempengaruhi nilai kalor yang dihasilkan, namun hal ini juga dipengaruhi adanya proses fermentasi yang harus sesuai dengan waktu yang ditentukan agar tidak terjadi penurunan pada glukosa yang dihasilkan. Terlihat pada gambar 2 terkait grafik hasil analisis Specific Gravity dan API Gravity menunjukkan nilai $\mathrm{R}^{2}$ mendekati 1 , artinya persamaan tersebut disimpulkan bahwa ada pengaruh terhadap kadar etanol yang terkandung pada sampel yang diberikan yaitu pisang hutan.

\section{Analisis Nilai Kalor Bioetanol}

Nilai kalor yang diperoleh dari hasil penelitian menunjukkan bahwa bahan buah pisang hutan mendekati nilai syarat mutu bioetanol. Dimana standar baku mutu bioetanol yang ditetapkan oleh Badan Standar Nasional (BSN) pada nilai kalor maksimal sebesar $5000 \mathrm{kkal} / \mathrm{kg}$. Terlihat pada kadar jumlah ragi sebesar 5\% dari bahan baku yang menunjukkan nilai kalor sebesar $3702,30 \mathrm{kkal} / \mathrm{kg}$. Nilai kalor pada kadar jumlah ragi $4 \%$ dari bahan baku diperoleh sebesar 1557,35 kkal/kg. Sedangkan nilai kalor terendah diperoleh dari kadar jumlah ragi sebesar 3\% yaitu 897,19 kkal/kg. 
Nilai kalor yang besar akan mempengaruhi proses pembakaran menjadi lebih mudah, sehingga kualitas bioetanol dapat dikatakan baik. Dari hasil nilai kalor bioetanol berbahan buah pisang hutan dengan dilakukannya proses destilasi sederhana masih menunjukkan hasil yang relatif rendah, namun sudah mendekati nilai standar baku mutu bioetanol.

Berdasarkan Gambar Grafik hasil Analisis Nilai Kalor Bioetanol dpat terlihat bahwa semakin besar kadar jumlah ragi yang diberikan dalam proses fermentasi, maka nilai kalor bioetanol berbahan buah pisang hutan yang dihasilkan semakin besar pula. Hal ini ditunjukkan dengan adanya pengaruh dari nilai API Gravity yang berbanding lurus dengan kadar jumlah ragi yang diberikan dan berbanding terbalik dengan hasil analisis densitas bioetanol yang diperoleh. Dimana hasil penelitian ini menunjukkan bahwa dengan adanya kadar jumlah ragi yang makin besar maka densitas yang diperoleh semakin kecil. Nilai kalor yang diperoleh dari hasil penelitian ini lebih tinggi dibandingkan dengan nilai kalor yang dihasilkan (12) pada biji durian sebesar 167,092 $\mathrm{kkal} / \mathrm{kg}$.

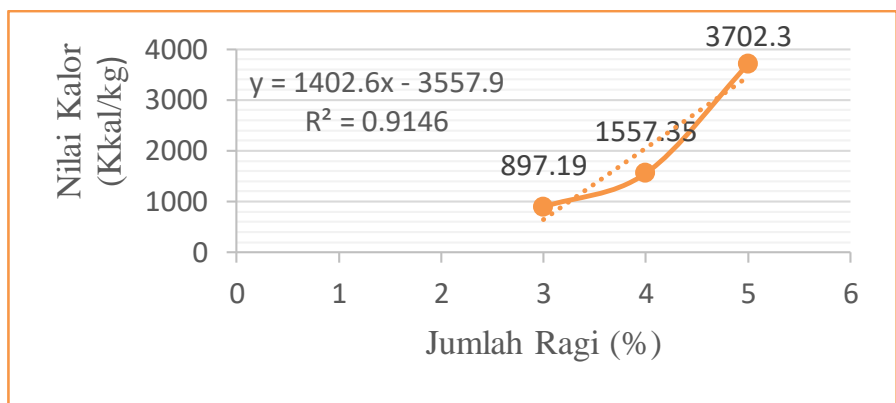

Gambar 5. Grafik Hasil Analisis Nilai Kalor Bioetanol

Nilai kalor pada hasil penelitian ini dipengaruhi oleh nilai API Gravity dan densitas. Hal ini disebabkan densitas bahan bakar diduga akan sangat berpengaruh terhadap laju konsumsi bahan bakar, semakin besar densitasnya diprediksi akan semakin meningkatkan konsumsi bahan bakar atau semakin boros (17). Artinya nilai densitas yang kecil akan menghasilkan nilai API Gravity dan nilai kalor yang besar sehingga kualitas dari bioetanol berbahan buah pisang dinyatakan mempunyai kualitas baik. Sebaliknya, nilai densitas yang besar akan menghasilkan nilai API Gravity dan nilai kalor yang kecil sehingga akan menghasilkan kualitas rendah. Terlihat pada gambar 3 terkait grafik hasil analisis Nilai Kalor Bioetanol menunjukkan nilai $\mathrm{R}^{2}$ mendekati 1 , artinya persamaan tersebut disimpulkan bahwa ada pengaruh terhadap kadar etanol yang terkandung pada sampel yang diberikan yaitu pisang hutan.

\section{SIMPULAN DAN SARAN}

\subsection{Simpulan}

Kesimpulan dari penelitian ini adalah : (1) Tahapan pengolahan buah pisang hutan menjadi bioetanol terdiri dari beberapa tahap, yaitu tahap penghalusan, fermentasi dengan ragi masingmasing 3\%, 4\%, 5\% dari bahan baku selama 7 hari dan dilanjutkan dengan proses destilasi. Bioetanol berbahan buah pisang hutan mempunyai potensi cukup baik untuk dikembangkan karena kualitas bioetanol yang dihasilkan memiliki nilai densitas dan specific gravity sesuai dengan standar mutu bioetanol yaitu sebesar 0,78 pada ragi 3\% dari bahan baku. Dan mempunyai nilai kalor yang punya hubungan erat dengan API Gravity mendekati nilai maksimum pada standar mutu bioetanol yaitu sebesar 3702,30 kkal/kg pada ragi sebesar 5\%. Nilai kadar etanol yang paling besar diperoleh pada kadar jumlah ragi sebesar 5\% yaitu 24,8\%. Nilai kadar Air yang paling rendah diperoleh pada kadar jumlah ragi sebesar $3 \%$ yaitu $75 \%$.

4.2 Saran

Saran untuk penelitian lebih lanjut dapat dilakukan terkait proses destilasi yang dilakukan. Sebaiknya menggunakan proses destilasi azeotrop agar hasil yang diperoleh lebih maksimal dan dapat dilakukan pengujian lebih lanjut untuk memastikan bahwa bioetanal dari buah pisang hutan dapat digunakan sebagai bahan bakar alternatif pada mesin bensin. 


\section{UCAPAN TERIMA KASIH}

Penulis mengucapkan terima kasih kepada Kementerian Riset, Teknologi dan Pendidikan Tinggi Republik Indonesia yang telah memberikan dana penelitian dalam program Penelitian Dosen Pemula (PDP).

\section{DAFTAR PUSTAKA}

1. Nugroho RM, Subagyo R. ANALISA VARIASI WAKTU FERMENTASI PEMBUATAN BIOETANOL DENGAN BAHAN AMPAS TEBU DAN KULIT PISANG. J Rotary. 2020;2(2):219-34.

2. Adistia NA, Nurdiansyah RA, Fariko J, Vincent V, Simatupang JW. Potensi Energi Panas Bumi, Angin, Dan Biomassa Menjadi Energi Listrik Di Indonesia. TESLA J Tek Elektro. 2020;22(2):105.

3. Romadhoni W, Sulaiman D, Purnama P. Analisis Potensi Pembangkit Listrik Tenaga Mikro Hydro Pada Anak Sungai di Bulungan. J Kumparan Fis. 2021;4(1):61-6.

4. Heltin $\mathrm{K}$, Fitryane L, Yusuf M. APROKSIMASI PERSAMAAN MAXWELLBOLTZMANN PADA ENERGI ALTERNATIF. 2013.

5. Firdausi NZ, Samodra NB, Hargono. PEMANFAATAN PATI SINGKONG KARET (Manihot glaziovii) UNTUK PRODUKSI BIOETANOL FUEL GRADE MELALUI PROSES DISTILASI-DEHIDRASI MENGGUNAKAN ZEOLIT ALAM. J Teknol Kim dan Ind. 2013;2(3):76-81.

6. Kurniati Y, Khasanah IE, Firdaus K. Kajian Pembuatan Bioetanol dari Limbah Kulit Nanas (Ananas comosus. L). J Tek Kim USU. 2021;10(2):95-101.

7. Marlina L, Hainun WN. Pembuatan Bioetanol dari Air Kelapa Melalui Fermentasi dan Destilasi-Dehidrasi Dengan Zeolit. J TEDC [Internet]. 2020;14(3):225-60. Available from: http://poltektedc.ac.id/ejournal/index.php/tedc/article/view/425

8. Khaidir, Setyaningsih D, Haerudin H. Dehidrasi bioetanol menggunakan zeolit alam termodifikasi. J Teknol Indusri Pertan. 2012;22(1):66-72.

9. Wusnah W, Bahri S, Hartono D. Proses Pembuatan Bioetanol dari Kulit Pisang Kepok (Musa acuminata B.C) secara Fermentasi. J Teknol Kim Unimal. 2019;8(1):48-56.

10. Amus F, Arofah KL, Widyastuti FK, Chandra A, Fitri K. Perbandingan Proses SHF \& SSF dalam Produksi Bioetanol dari Bonggol Pisang Kepok. In: Prosiding Seminar Nasional Teknologi Industri, Lingkungan dan Infrastruktur (SENTIKUIN). 2020. p. C9.1-C9.4.

11. Sulistyaningsih LD, Wawo AH. Kajian Etnobotani Pisang-pisang Liar (Musa spp.) Di Malinau, Kalimantan Timur. Biosfera. 2011;28(1):43-7.

12. Hanum F, Pohan N, Rambe M, Primadony R, Ulyana M. Pengaruh Massa Ragi Dan Waktu Fermentasi Terhadap Bioetanol Dari Biji Durian. J Tek Kim USU. 2013;2(4):49-54.

13. Retno DT, Nuri W. Pembuatan Bioetanol dari Kulit Pisang. In: Prosiding Seminar Nasional Teknik Kimia “Kejuangan” Pengembangan Teknologi Kimia untuk Pengolahan Sumber Daya Alam Indonesia. 2011. p. E11-1-E11-7.

14. Bestari A, Sutrisno E, Sumiyati S. PENGARUH LAMA FERMENTASI TERHADAP KADAR BIOETANOL DARI LIMBAH KULIT PISANG KEPOK DAN RAJA. J Tek Lingkung. 2013;2(3):1-6.

15. Khodijah S, Abtokhi A. ANALISIS PENGARUH VARIASI PERSENTASE RAGI (Saccharomyces cerevisiae) DAN WAKTU PADA PROSES FERMENTASI DALAM PEMANFAATAN DUCKWEED (Lemna minor) SEBAGAI BIOETANOL. J Neutrino. 2015;7(2):71-6.

16. Purnama R, Yuliadi H, Aritonang B, Zambak MF, Kurniawan F. Menggali Potensi Energi Listrik "Energi Baru Terbarukan" Bersumber Dari Produksi Kelapa Sawit Biomassa Di Aceh Tamiang. Vortex. 2021;1(2):94.

17. Wijaya IMAS, Arthawan IGKA. Potensi nira kelapa sebagai bahan baku bioetanol. J Bumi Lestari. 2012;12(1):85-92. 